\title{
PENGARUH KEADILAN ORGANISASI, PERSEPSI DUKUNGAN ORGANISASI DAN KOMITMEN ORGANISASI TERHADAP KONTRIBUSI KARYAWAN PENSIUN
}

\author{
MAYA ARISANDY \\ Jurusan Akuntansi, STIE Al Khairiyah Citangkil \\ *Email : mayarisandy25@gmail.com
}

\begin{abstract}
This study examined the effect of effect of organization fairness, perceived organization support and organization commitment to organizational citizenship behavior for company. The object of this research is a pension employee of PT Krakatau Steel, which is in the province of Banten, especially in Cilegon branch. 10 branches serve as a sample with 140 questionnaires distributed, but the questionnaire which can be processed as many as 100 questionnaires. Questions questionnaire measured with a scale of 1-5. Data were analyzed by using SEM (Structural Equation Model) through SmartPLS (Partial Least Square) 1:10 version. The results of this study expressed that hypotesis from organizational fairness, perceived organization support and organization commitment is positive effect and significant to organizational citizenship behaviour for company.
\end{abstract}

\section{Keywords: Organizational Fairness; Perceived Organizational Support; Organizatinal Commitment; Organizational Citizenship Behaviour}

\section{PENDAHULUAN}

Pengelolaan SPM saat ini merupakan suatu keharusan dan bukan lagi merupakan suatu pilihan apabila perusahaan ingin berkembang. Sistem Pengendalian Manajemen merupakan hal yang sangat penting dalam suatu organisasi, karena keefektifan dan keberhasilan suatu organisasi sangat tergantung pada kualitas dan kinerja sumber daya manusia yang ada pada organisasi tersebut. Kinerja sumber daya manusia (karyawan) yang tinggi akan mendorong munculnya Organizational Citizenship Behavior (OCB), yaitu perilaku melebihi apa yang telah distandarkan perusahaan (Krietner dkk, 2003). Organizational Citizenship Behavior dapat timbul dari berbagai faktor dalam organisasi, di antaranya karena adanya keadilan orgnaisasi, persepsi dukungan organisasi dan komitmen organisasi yang tinggi (Robbin dan Judge, 2007). Begitu juga dengan ketika seseorang mempunyai komitmen yang tinggi terhadap organisasinya, maka orang tersebut akan melakukan apapun untuk memajukan perusahaannya karena keyakinannya terhadap organisasinya (Luthans, 2005). Ketika seseorang mendapatkan keadilan dan dukungan serta mempunyai komitmen yang tinggi terhadap organisasi, karyawan akan memberikan pelayanan yang baik dan begitu 
juga sebaliknya, ketika karyawan saja tidak mengalami keadilan dan dukungan maka kinerja karyawan diperediksi kurang baik. (Nawawi, 2008). Keadilan dan dukungan organisasi merupakan suatu hal yang dapat memberikan pengaruh terhadap perilaku organisasi yang dapat bersifat positif dan negatif, yang seterusnya juga akan berpengaruh pada kinerja individu dan kelompok serta kinerja perusahaan atau organisasi.

Organ menyatakan bahwa OCB adalah sebuah tipe spesial dari kebiasaan kerja yang didefinisikan sebagai perilaku individu yang sangat menguntungkan untuk organisasi dan merupakan kebebasan memilih, secara tidak langsung atau secara eksplisit diakui oleh sistem penghargaan formal. Organ mengatakan bahwa tidak semua hal dengan ciri yang berbeda dari OCB akan membuat perbedaan pada hasil dalam organisasi atau jika ada keinginan di mana banyak orang yang secara terus menerus memberikan bantuan pada pekerja lainnya akan memberikan sumbangsih pada efektivitas organisasi mereka. Pada dasarnya, ketika karyawan merasakan keadilan dan dukungan maka akan memunculkan komitmen penuh pada perusahaan dan mampu memunculkan perilaku OCB (Kasemsap, 2012)

Seseorang yang sudah tidak bekerja lagi karena usianya sudah lanjut atau atas kemauan sendiri sehingga harus diberhentikan dinamakan dengan Pensiun. Saat pensiun, seseorang akan mendapatkan hak uang pensiun, uang pesangon dan uang penghargaan. (Hasibuan 2001:205) Di dalam proses pelaksanaannya para penerima pensiun dapat memilih salah satu dari beberapa jenis pensiun yang ditawarkan, dengan melihat situasi dan kondisi yang terjadi. Beberapa jenis pensiun yang ditawarkan oleh perusahaan di antaranya: 1. Pensiun Normal 2. Pensiun Dipercepat 3. Pensiun Ditunda 4. Pensiun Cacat. Kegiatan lumrah yang di lakukan oleh para pensiunan adalah menikmati masa tua dan tidak ingin terlibat lagi dengan suatu pekerjaan yang berat karena fisik yang sudah tidak lagi kuat dan penyakit yang rentan menghinggapi tubuh berhubung usia pun sudah senja. (Mathis dan Jackson 2002:215)

Organ et al. (2006) dalam hal ini mendefinisikan "Organizational Citizenship Behavioras Individual behavior that is discretionary, not directly or explicitly recognized by the formal reward system, and in the aggregate promotes the efficient and effective functioning of the organization." Dalam suatu perusahaan, beberapa karyawan pensiunan masih meningkatkan pemasaran perusahaan dan juga memberikan benefit terhadap perusahaan, meskipun sudah mendapat jaminan kesehatan, jaminan untuk keluarga, jaminan waris, dll. (Fogarty Et al, 2000), meningkatkan pemasaran bagi para mantan karyawan (Marxen, 2006), dan kemampuan alumni secara signifikan menguntungkan mantan perusahaan mereka. Akuntan Expublic bekerja di posisi akuntansi dan keuangan dengan perusahaan lain yang dapat memiliki pengaruh besar dalam menyediakan bisnis baru bagi perusahaan mereka.

Cropanzano et al. (2007) menyatakan bahwa terdapat tiga alasan mengapa karyawan peduli dan berkontribusi terhadap perusahaan. Pertama, manfaat jangka panjang. Kedua, pertimbangan sosial. Ketiga, pertimbangan etis. Perusahaan dalam memberikan kompensasi kepada para pekerja terlebih dahulu melakukan penghitungan kinerja dengan membuat sistem penilaian kinerja yang adil. Sistem tersebut umumnya berisi kriteria penilaian setiap pegawai yang ada misalnya 
mulai dari jumlah pekerjaan yang bisa diselesaikan, kecepatan kerja, komunikasi dengan pekerja lain, perilaku, pengetahuan atas pekerjaan, dan lain sebagainya.

Keadilan organisasi adalah sebuah topik yang sudah menjadi bahan riset sejak lebih dari 25 tahun lalu (Colquitt et al., 2001). Cropanzano et al. (2007) mendefinisikan keadilan organisasi sebagai penilaian personal mengenai standar etika dan moral dari perilaku manajerial. Dalam menilai keadilan organisasi setidaknya terdapat tiga bidang yang harus dievaluasi, yaitu: imbalan, proses, dan hubungan interpersonal (Cropanzano et al., 2001). Banyak riset yang kemudian menguji keadilan organisasi dengan tiga komponen, yaitu: distributif, prosedural, dan interaksional (Cohen-Carash et al, 2001). Greenberg (1987) menyatakan bahwa keadilan interaksional terdiri dari dua komponen, yaitu: interpersonal dan informasional. Persepsi dukungan organisasi mengacu pada persepsi karyawan mengenai sejauh mana organisasi menilai, memberi dukungan, dan peduli pada kesejahteraan mereka (Rhoades et al, 2002).

Dari berbagai organisasi ditemukan bahwa karyawan yang merasa dirinya mendapatkan dukungan dari organisasi akan memiliki rasa kebermaknaan dalam diri karyawan tersebut. Hal inilah yang akan meningkatkan komitmen pada diri karyawan. Komitmen inilah yang pada akhirnya akan mendorong karyawan untuk berusaha membantu organisasi mencapai tujuannya, dan meningkatkan harapan bahwa performa kerja akan diperhatikan serta dihargai oleh organisasi (Rhoades \& Eisenberger, 2002). Bagi karyawan, organisasi merupakan sumber penting bagi kebutuhan sosioemosional mereka seperti respect (penghargaan), caring (kepedulian), dan tangible benefit (keuntungan nyata) seperti gaji dan tunjangan kesehatan. Perasaan dihargai oleh organisasi membantu mempertemukan kebutuhan karyawan terhadap approval (persetujuan), esteem (penghargaan) dan affiliation (keanggotaan) (Eisenberger \& Rhoades, 2002). Seseorang yang bergabung dalam organisasi pada sebuah perusahaan dituntut adanya komitmen dalam dirinya. Sebagai definisi yang umum, dalam buku Setiadi (2004:50) mengartikan komitmen organisasi sebagai sikap yang menunjukkan "loyalitas" karyawan dan merupakan proses berkelanjutan bagaimana seorang anggota organisasi mengekspresikan perhatian mereka kepada kesuksesan dan kebaikan organisasinya. Komitmen mencakup juga keterlibatan kerja. Hal ini disebabkan karena antara keterlibatan kerja dengan komitmen organisasi sangat erat hubungannya. Keterlibatan kerja sebagai derajat kemauan untuk menyatukan dirinya dengan pekerjaan, menginvestasikan waktu, kemampuan dan energinya untuk pekerjaan, dan menganggap pekerjaannya sebagai bagian utama dari kehidupannya, Tri Mardiana (2004:177). Komitmen seseorang terhadap organisasi atau perusahaan seringkali menjadi isu yang sangat penting. Karena pentingnya hal tersebut, beberapa organisasi memasukkan unsur komitmen sebagai salah satu syarat untuk memegang suatu jabatan atau posisi yang ditawarkan dalam iklaniklan lowongan pekerjaan (Kuntjoro, 2002).

Penelitian ini adalah pengembangan dari Jurnal The effects of organizational fairness and commitment on the extent of benefits big four alumni provide their former firm yang menjadi jurnal pendukung utama penelitian ini telah memilih beberapa varians variabel berdasarkan penelitian yang dilakukan oleh David N. Herda dan James J. Lavelle 2011 yaitu: Peran keadilan organisasi 
(Organization Fairness), Persepsi Dukungan organisasi (Perceived Organization support), Komitmen organisasi (Commitment organization) dan Kontribusi Karyawan Pensiun (Organizational Citizenship Behaviour). Yang membedakan penelitian ini dengan penelitian sebelumnya (David N. Herda dan James J. Lavelle 2011) yaitu penelitian ini menggunakan model intervening dan menambah 1 hipotesis. Dalam penelitian ini menggunakan sample alumni pekerja dari PT Krakatau Steel sedangkan penelitian terdahulu dari alumni auditor kantor Big Four.

\section{LANDASAN TEORI}

\section{Teori Pertukaran Sosial}

Teori pertukaran sosial memiliki asumsi bahwa orang akan secara sukarela memasuki dan tinggal dalam suatu interaksi sosial dengan mempertimbangkan konsekuensi yang terjadi yaitu untung rugi. Pada dasarnya, dalam membangun sebuah interaksi sosial yang memungkinkan individu untuk memaksimalkan keuntungan yang diperoleh. Prinsip dasar pertukaran sosial adalah "distributive justice" yaitu suatu aturan yang mengatakan bahwa sebuah imbalan harus sebanding dengan investasi. Dalam teori pertukaran sosial yang menggunakan ekonomi sebagai landasan teorinya bahwa orang berusaha membangun hubungan persahabatan atau percintaan yang hanya akan memberikan keuntungan yang lebih besar. (Thibaut dan Kelley, 1978) Sabatelli dan Pearce (1986) melakukan penelitian terhadap individu yang telah melakukan hubungan pernikahan, ditemukan bukti bahwa rasa percaya yang tinggi merupakan hal yang sangat diharapkan oleh pasangan suami istri. Disetiap kehidupan manusia sebagai individu memiliki berbagai alternatif dari comparison level sebagai perbandingan dari keuntungan yang diperoleh dalam suatu interaksi sosial.

Organ (1988) mengusulkan bahwa keadilan organisasi mengarah pada perilaku organni pada organisasi karena keadilan menyebabkan hubungan pertukaran sosial untuk mengembangkan antara karyawan dan supervisor mereka. Secara garis besar, keadilan organisasi dapat didefinisikan sebagai persepsi karyawan kewajaran kondisi kerja mereka (Folger \& Cropanzano, 2008). Moorman (2001) menemukan bahwa keadilan diprediksi pada perilaku organisasi karyawan pensiun di kalangan pekerja di dua perusahaan manufaktur menengah. Ulasan yang terbaru dan studi empiris terus menunjukkan efek keadilan organisasi terhadap perilaku kontribusi pada organisasi dan sikap karyawan seperti komitmen organisasi. Sebagai contoh, menggunakan model exchange berbasis sosial, Lavelle et al. (2009) menemukan efek mediasi komitmen pada hubungan positif antara keadilan prosedural dan perilaku kontribusi pada organisasi antara korban PHK. Teori pertukaran sosial telah terbukti menjadi kerangka berharga untuk menyelidiki perilaku prediktor karyawan pensiun (Podsakoff, et al, 2000) dan oleh karena itu digunakan dari teori ini untuk menginformasikan penelitian ini pada karyawan pension

\section{Pengembangan Hipotesis}




\section{Pengaruh keadilan organisasi (Organization Fairness) terhadap Kontribusi Karyawan Pensiun (Organizational Citizenship Behavior)}

Efek positif dari pertukaran sosial yang dikembangkan selama masa kerja individu dengan organisasi dalam jangka panjang saat bekerja dengan organisasi dan memanifestasikan dirinya dalam bentuk kontribusi karyawan pensiun. Penelitian sebelumnya menunjukkan bahwa perlakuan yang adil oleh perusahaan sangat penting untuk mengembangkan hubungan pertukaran sosial (Lavelle et al., 2007). Akibatnya, model dari karyawan pensiun dimulai dengan fokus pada keadilan organisasi. Penelitian menunjukkan bahwa perlakuan adil memfasilitasi pembentukan hubungan pertukaran sosial (Cropanzano \& Mitchell, 2005). Secara khusus, seberapa adil organisasi memperlakukan karyawan mereka (yaitu, keadilan organisasi) menjadi indikator sejauh mana karyawan merasa bahwa organisasi peduli tentang kesejahteraan mereka dan mendukung mereka (yaitu, persepsi dukungan organisasi).

Lavelle dan rekan (2007) mengakui urutan ini dalam target kesamaan model mereka dan disebut sebagai fase satu dan tahap dua dari hubungan pertukaran sosial. Sebelum studi empiris dalam literatur organisasi menawarkan dukungan untuk kemajuan ini (Eisenberger, Fasolo, \& Davis-LaMastro, 2000; Rhoades \& Eisenberger, 2002; Shore \& Wayne, 2003).

Berdasarkan uraian di atas, maka diajukan hipotesis penelitian sebagai berikut:

H1. Peran keadilan organisasi berpengaruh positif terhadap konribusi karyawan pensiun (Organizational Citizenship Behavior) kepada perusahaan.

\section{Pengaruh Keadilan Organisasi (Organizational Fairness) Terhadap Komitmen Organisasi (Organizational Commitment)}

Beberapa penelitian dan meta-analisis telah menunjukkan keadilan organisasi terhadap komitmen organisasi yang akan langsung berhubungan dengan perilaku kontribusi pada organisasi (Burney, Henle, \& Widener, 2009; Cohen-Charash \& Spector, 2001; Colquitt, Conlon, Wesson, Porter, \& Ng , 2001; Lepine, Erez, \& Johnson, 2002; Moorman, 2001; Viswesvaran \& Ones, 2002).

Model relasional keadilan organisasi (misalnya, Tyler \& Lind, 2002) menunjukkan bahwa perlakuan yang adil sangat penting untuk karyawan sebagian karena menyampaikan rasa memiliki dan melambangkan bahwa karyawan adalah anggota dihargai dan dihormati organisasi. Konsisten dengan perspektif ini, Moorman et al. (2008) menemukan bahwa keadilan prosedural positif yang diperkirakan serta komitmen organisasi dalam sebuah penelitian yang melibatkan pekerja rumah sakit. Rhoades, Eisenberger, dan Armeli (2001) meneliti sampel beragam jenis pekerjaan dan organisasi dan juga menemukan bahwa keadilan prosedural terkait erat dengan komitmen organisasi. Akhirnya, dalam meta-analisis, Rhoades dan Eisenberger (2002) menemukan bahwa keadilan organisasi merupakan prediktor kuat dari komitmen organisasi. Berdasarkan uraian di atas, maka diajukan hipotesis penelitian sebagai berikut:

H2. Keadilan organisasi berpengaruh positif terhadap komitmen organisasi. 
Pengaruh Komitmen Organisasi (Organizational Commitment) terhadap Kontribusi Karyawan Pensiun (Organizational Citizenship Behavior)

Penelitian menunjukkan bahwa komitmen organisasi dapat dilihat sebagai indikator sikap dari sejauh mana seorang karyawan memandang dirinya sendiri untuk berada dalam hubungan pertukaran sosial berkualitas tinggi dengan organisasi (Cropanzano \& Mitchell, 2005). Hubungan pertukaran sosial berkualitas tinggi cenderung mendorong karyawan untuk terlibat dalam pensiunan karena karyawan akan merasa kewajiban relasional untuk terlibat dalam perilaku yang memiliki konsekuensi positif bagi mitra hubungan mereka (Lavelle et al, 2007;. Van Dyne, Graham, \& Dienesch, 2004). Konsisten dengan penalaran ini, penelitian empiris baru-baru ini menunjukkan hubungan positif antara komitmen organisasi dan perilaku warga organisasi (Becker \& Kernan, 2003;. Lavelle et al, 2009).

Komitmen organisasi secara konseptual sebanding dengan perilaku karyawan perusahaan dalam keduanya melibatkan manfaat organisasi yang murni diskresioner pada bagian dari individu. Komitmen organisasi, ditandai dengan ikatan emosional antara individu dan perusahaan, dapat mengurangi keinginan berpindah, sehingga memperpanjang masa kerja (misalnya, Parker \& Kohlmeyer, 2005). Selain itu, sebagai hubungan pertukaran sosial berkualitas tinggi mengakibatkan karyawan mengambil fokus jangka panjang, disarankan fokus ini dapat terus berlanjut setelah karyawan meninggalkan perusahaan. Akibatnya, komitmen organisasi dapat memprediksi kontribusi karyawan pensiun sebagai rasa kewajiban relasional yang masih tetap ada setelah masa kerja berakhir. Berdasarkan uraian di atas, maka diajukan hipotesis penelitian sebagai berikut:

H3. Komitmen organisasi berpengaruh positif terhadap kontribusi karyawan pensiun (Organizational Citizenship Behavior) kepada perusahaan.

\section{Pengaruh Persepsi Dukungan Organisasi (Perceived rganizational Support) terhadap Komitmen Organisasi (Organizational Commitment)}

Dukungan organisasi dan komitmen organisasi adalah dua variabel yang telah digunakan sebagai indikator hubungan pertukaran sosial karyawan dengan organisasi. Para peneliti menunjukkan bahwa ketika karyawan merasa dukungan dari organisasi, karyawan akan merasakan suatu kewajiban untuk membalas dukungan yang dalam bentuk sikap yang menguntungkan terhadap organisasi, seperti komitmen (Lavelle et al., 2007). Lavelle dan rekan (2007) dalam target kesamaan model mereka dan disebut sebagai fase satu dan tahap dua dari hubungan pertukaran sosial. Sebelum studi empiris dalam literatur organisasi menawarkan dukungan untuk kemajuan ini(Eisenberger, Fasolo, \& DavisLaMastro, 2000; Rhoades \& Eisenberger, 2002; Shore \& Wayne, 2003). Sebagai contoh, Eisenberger et al. (2000) menemukan bahwa persepsi organisasi mendukung prediksi komitmen organisasi. Berdasarkan uraian di atas, maka diajukan hipotesis penelitian sebagai berikut:

H4. Persepsi dukungan organisasi berpengaruh positif terhadap komitmen organisasi 
Pengaruh peran Persepsi Dukungan Organisasi (Perceived Organizational Support) terhadap Kontribusi Karyawan Pensiun (Organizational Citizenship Behavior)

Organ's(1988, 2000) melihat bahwa karyawan mungkin terlibat dalam perilaku kontribusi pada organisasi untuk membalas perlakuan yang adil dari organisasi. Mengingat kesamaan konseptual antara perilaku kontribusi pada organisasi dan karyawan pensiun, sangat beralasan untuk percaya bahwa persepsi dukungan organisasi juga akan memprediksi kontribusi karyawan pensiun.

Para peneliti menunjukkan bahwa ketika karyawan merasa mendapat dukungan dari organisasi, karyawan akan merasakan suatu kewajiban untuk membalas dukungan yang dalam bentuk sikap yang menguntungkan terhadap organisasi (Lavelle et al., 2007). Urutan ini diakui oleh Lavelle dan rekan (2007) dalam target kesamaan model mereka dan disebut sebagai fase satu dan tahap dua dari hubungan pertukaran sosial. Sebelum studi empiris dalam literatur organisasi menawarkan dukungan untuk kemajuan ini (Eisenberger, Fasolo, \& Davis-LaMastro, 2000; Rhoades \& Eisenberger, 2002; Shore \& Wayne, 2003). Sebagai contoh, Eisenberger et al. (2000) menemukan bahwa persepsi organisasi mendukung kontribusi karyawan pensiun dari waktu ke waktu menggunakan data longitudinal tetapi sebaliknya (karyawan memprediksi persepsi dukungan organisasi) tidak terjadi. Berdasarkan uraian di atas, maka diajukan hipotesis penelitian sebagai berikut:

H5. Peran dukungan organisasi berpengaruh positif terhadap kontribusi karyawan pensiun (Organizational Citizenship Behavior) kepada perusahaan

\section{METODOLOGI PENELITIAN}

\section{Populasi dan Sampel}

Populasi adalah kumpulan dari seluruh elemen sejenis tetapi dapat dibedakan satu sama lain. Perbedaan-perbedaan itu disebabkan karena adanya nilai karakterisktik yang berlainan (Supranto, 2000). Populasi dari penelitian ini adalah karyawan pensiun dari perusahaan PT Krakatau Steel. Alasan memilih populasi tersebut adalah karena mantan karyawan perusahaan tersebut masih berkontribusi dan meningkatkan benefit terhadap perusahaan. Ini terbukti dengan adanya PPPKS (Persatuan Pensiun PT Krakatau Steel) yang masih aktif dan menjalin silaturahmi yang baik dengan perusahaan.

Sedangkan teknik penarikan sampel dalam penelitian ini adalah dengan menggunakan purposive sampling methode (pemilihan sampel bertujuan). Teknik tersebut dipilih karena jumlah populasi yang tidak dapat diukur dengan pasti jumlahnya dan peneliti mempunyai pertimbangan-pertimbangan atau tujuan tujuan tertentu di dalam pengambilan sampelnya. Kriteria sampel yang diajukan dalam penelitian ini adalah sebagai berikut : 1. Karyawan yang berdomisili tinggal di Banten. 2. Karyawan yang pensiun bukan karena PHK atau cacat. 3. Karyawan pensiun aktif yang berkontribusi kepada perusahaan.

\section{Metode analisis data}


Setelah data yang diperlukan diolah, maka dilakukan analisis sehingga data tersebut dapat terjadi lebih berarti. Untuk memperkirakan jalur antara konstruksi yang ditunjukkan dalam model penelitian, peneliti menggunakan PLS, yaitu software yang berfungsi untuk menganalisis data dan melakukan perhitungan statistik baik paremetrik maupun non parametrik dengan basis windows.

\section{HASIL PENELITIAN DAN PEMBAHASAN}

\section{Analisis Statistik Deskriptif}

Untuk lebih memperjelas objek yang diteliti akan dikemukakan gambaran umum mengenai demografi responden penelitian meliputi usia, jenis kelamin, jangka waktu berlalu sejak responden meninggalkan perusahaan, lama bekerja di perusahaan, dan tingkat kontak saat ini dengan mantan perusahaan. (Ghozali, 2011). Penelitian ini dilakukan dengan penyebaran kuesioner, jumlah kuesioner yang disebarkan sebanyak 140 kuesioner pada 10 ranting, namun kuesioner yang kembali berjumlah 136 kuesioner atau sebanyak 97.14\%. Jumlah kuesioner yang dapat diolah sebanyak 100 kuesioner atau hanya $71.42 \%$ dan kuesioner yang tidak kembali berjumlah 4 kuesioner atau $2.86 \%$, kuesioner yang tidak kembali disebabkan responden tengah sibuk sehingga tidak sempat untuk menjawab kuesioner.

\section{Uji Kualitas Data}

Uji kualitas data yang dilakukan pada penelitian ini meliputi uji reliabilitas dan uji validitas dengan menggunakan software smart Partial Least Square (PLS). PLS adalah model persamaan struktural (SEM) yang berbasis komponen atau SEM yang berbasis kovarian umumnya menguji kausalitas/teori sedangkkan PLS lebih bersifat predictive model. PLS merupakan metode analisis yang powerfull (Wold, 1985 dalam Ghozali, 2006) karena tidak didasarkan pada banyak asumsi.

\section{Uji Validitas}

Uji validitas digunakan untuk mengukur sah atau valid tidaknya suatu kuesioner. Suatu kuesioner dikatakan valid jika pertanyaan pada kuesioner tersebut mampu untuk mengungkapkan sesuatu yang akan diukur oleh kuesioner tersebut. Pengujian validitas data dalam penelitian ini adalah dengan menggunakan software SmartPLS dengan Outer Model, yaitu Convergent validity yang dilihat dengan nilai square root of average variance extracted (AVE) masing-masing konstruk di mana nilainya harus lebih besar dari 0,5 (Chin dalam Ghozali, 2006).

Cara lain yaitu dengan membandingkan nilai square root of average variance extracted (AVE) setiap Konstruk (variabel laten) dengan Korelasi antara konstruk dengan konstruk lainnya dalam model. Apabila nilai akar kuadrat dari AVE untuk setiap konstruk lebih besar daripada nilai korelasi antara konstruk dengan konstruk lainnya dalam model, maka masingmasing indikator pernyataan adalah 
valid (Ghozali, 2006) atau dikatakan memiliki nilai Discriminant validity yang baik.

Tabel 4.1 Average Variance Extracted (AVE)

\begin{tabular}{|c|c|c|c|}
\hline & Average Variance Extracted (AVE) \\
\begin{tabular}{|c|c|c|c|}
\hline & $\begin{array}{c}\text { Average variance } \\
\text { extracted (AVE) }\end{array}$ & VAVE & Keterangan \\
\hline Keadilan Organisasi (KEO) & 0.654 & 0.808 & Valid \\
\hline $\begin{array}{c}\text { Persepsi Dukungan Organisasi } \\
\text { (PDO) }\end{array}$ & 0.589 & 0.767 & Valid \\
\hline Komitment Organisasi (KO) & 0.779 & 0.882 & Valid \\
\hline $\begin{array}{c}\text { Kontribusi Karyawan Pensiun } \\
\text { (KKP) }\end{array}$ & 0.782 & 0.884 & Valid \\
\hline
\end{tabular}
\end{tabular}

Sumber: Output SmartPLS, 2018

Tabel 4.2 Correlations of Latent Variables

Composite Reliability
\begin{tabular}{|c|c|c|}
\hline & $\begin{array}{c}\text { Composite } \\
\text { Reliability }\end{array}$ & Keterangan \\
\hline Keadilan Organisasi (KO) & 0.883 & Reliabel \\
\hline Persepsi Dukungan Organisasi (PDO) & 0.850 & Reliabel \\
\hline Komitment Organisasi (KO) & 0.934 & Reliabel \\
\hline Kontribusi Karyawan Pensiun (KKP) & 0.915 & Reliabel \\
\hline
\end{tabular}

Sumber: Output SmartPLS, 2018

Tabel Correlations of Latent Variables menjelaskan nilai dari AVE dan akar AVE dari konstruk keadilan organisasi, persepsi dukungan organisasi, komitment organisasi dan kontribusi karyawan pensiun. Dapat dilihat bahwa setiap konstruk (variabel) tersebut memiliki nilai AVE diatas 0.5. Hal ini menunjukkan bahwa setiap konstruk tersebut memiliki nilai validitas yang baik dari setiap indikatornya atau kuesioner yang digunakan untuk mengetahui pengaruh keadilan organisasi, persepsi dukungan organisasi, komitment organisasi dan kontribusi karyawan pensiun dapat dikatakan valid.

Cara lain yang dapat digunakan untuk menilai validitas suatu konstruk adalah dengan membandingkan akar kuadrat dari AVE yang terdapat dalam Tabel Correlations of Latent Variables dengan korelasi dari variabel laten yang terdapat dalam Tabel Composite Reliability. Hasil yang didapat menyatakan bahwa akar AVE lebih kecil apabila dibandingkan dengan korelasi variabel laten, hal ini dapat diartikan bahwa pernyataan dalam kuesioner dinyatakan tetap valid karena semua konstruk dalam model yang diestimasi memenuhi salah satu kriteria yang berlaku.

\section{Uji reliabilitas}

Uji reliabilitas dimaksudkan untuk mengukur internal consistency suatu kuesioner yang merupakan indikator dari variabel atau konstruk. Suatu kuesioner dikatakan reliabel jika jawaban seseorang terhadap pernyataan menghasilkan jawaban yang sama dari waktu ke waktu. Pengujian reliabilitas data dalam 
penelitian ini menggunakan software SmartPLS dengan kriteria uji Composite reliability. Suatu data dikatakan reliabel jika Composite reliability lebih besar dari 0.7 (Ghozali, 2006).

Tabel 4.3 Composite Reliability

\begin{tabular}{|lll|}
\hline & Composite Reliability & Keterangan \\
Keadilan Organisasi (KEO) & 0.883 & Reliabel \\
Persepsi Dukungan Organisasi & 0.850 & Reliabel \\
Komitment Organisasi (KO) & 0.934 & Reliabel \\
Kontribusi Karyawan Pensiun & 0.915 & Reliabel \\
\hline
\end{tabular}

Sumber: Output SmartPLS, 2019

Dari Tabel Composite Reliability dapat dilihat setiap konstruk atau variabel laten tersebut memiliki nilai composite reliability diatas 0.7 yang menandakan bahwa internal consistency dari variabel independen (keadilan organisasi, persepsi dukungan organisasi dan komitment organisasi), dan variabel dependen (kontribusi karyawan pensiun) memiliki reliabilitas yang baik.

\section{Analisis Data}

\section{Menilai Outer Model (Measurement Model)}

Model measurement dilakukan untuk menguji hubungan (nilai loading) antara indikator dengan konstruk (variabel laten). Dalam menilai outer model dalam PLS terdapat tiga kriteria, salah satunya adalah melihat Convergent validity, sedangkan untuk dua kriteria yang lain yaitu Discriminant validity dalam bentuk square root of average variance extracted (AVE) dan Composite Reliability telah dibahas sebelumnya pada saat pengujian kualitas data. Untuk Convergent validity dari model pengukuran dengan refleksif indikator dinilai berdasarkan Korelasi antara item score/component score yang diestimasi dengan software Smart PLS. Ukuran refleksif individual dikatakan tinggi jika berKorelasi lebih dari 0.7 dengan konstruk (variabel laten) yang diukur. Namun menurut Chin (dalam Ghozali 2006), untuk penelitian tahap awal dari pengembangan, skala pengukuran nilai loading 0.5 sampai 0.6 dianggap cukup memadai.

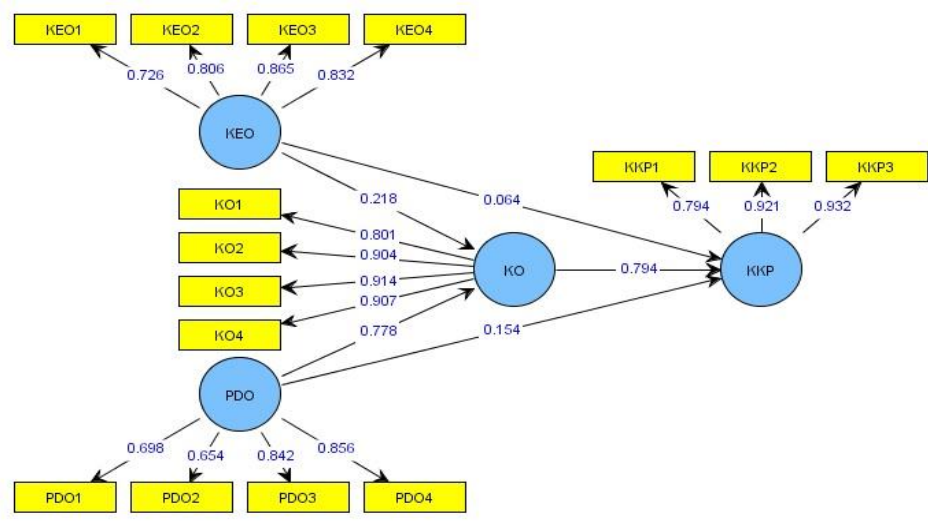

Gambar 4.1 Model Structural Partial Least Square 
Berikut dapat dilihat secara keseluruhan korelasi setiap variabel pada Gambar Full Model Structural Partial Least Square, yaitu gambar yang menyatakan pengaruh keadilan organisasi, persepsi dukungan organisasi, komitment organisasi dan kontribusi karyawan pensiun. Di mana model pada Gambar Full Model Structural Partial Least Square tidak dilakukan eliminasi, hal ini disebabkan karena tidak terdapat korelasi konstruk yang kurang dari 0.5 sehingga setiap variabel memenuhi kriteria Convergent validity. Dalam pembahasan selanjutnya akan dibahas mengenai hubungan korelasi dari setiap variabel independen dan variabel dependen.

\section{Pengujian Hipotesis melalui Inner Model}

Inner model menurut Ghozali (2006) merupakan gambaran hubungan antar variabel laten yang berdasarkan pada substantive theory Inner model yang kadang disebut juga dengan inner relation, structural model dan substantive theory. Pengujian inner model atau model struktural dilakukan untuk melihat hubungan antara konstruk, nilai signifikasi dan $R$-square dari model penelitian. Model struktural dievaluasi dengan mengggunakan Rsquare untuk konstruk dependen (Ghozali, 2006). Batas untuk menolak dan menerima hipotesis yang diajukan yaitu $\pm 1,96$, di mana apabila nilai T-statistik lebih besar dari T-tabel $(1,96)$ maka hipotesis diterima, sebaliknya jika nilai T-statistik lebih kecil dari Ttabel $(1,96)$ maka hipotesis ditolak. Adapun inner model dalam penelitian ini adalah sebagai berikut:

Sumber: Output SmartPLS, 2019

\section{Tabel 4.5 Result For Inner Weight}

\begin{tabular}{|l|l|l|l|l|l|}
\hline & $\begin{array}{l}\text { Original } \\
\text { Sample } \\
\text { Estimate }\end{array}$ & $\begin{array}{l}\text { Mean Of } \\
\text { Subsample } \\
\text { s }\end{array}$ & $\begin{array}{l}\text { Standard } \\
\text { Deviation }\end{array}$ & T-Statistic & Hipotesis \\
\hline KEO -> KKP & 0.064 & 0.060 & 0.030 & 2.135 & Diterima \\
\hline KEO -> KO & 0.218 & 0.217 & 0.050 & 4.380 & Diterima \\
\hline KO -> KKP & 0.794 & 0.797 & 0.055 & 14.492 & Diterima \\
\hline PDO -> KO & 0.778 & 0.781 & 0.046 & 16.944 & Diterima \\
\hline PDO -> KKP & 0.514 & 0.154 & 0.051 & 3.046 & Diterima \\
\hline
\end{tabular}

Berdasarkan tabel Result For Inner Weight terlihat bahwa hubungan KEO dalam variabel $\mathrm{KO}$ sebesar 0,218 dan signifikan dengan t-statistik lebih besar dari nilai t-tabel $(4.380>1,96)$. Untuk hubungan PDO dalam KO sebesar 0,778 dan signifikan dengan t-statistik lebih besar dari nilai t-tabel $(16.944>1,96)$. Untuk hubungan KEO dalam variabel KKP sebesar 0,064 dan signifikan dengan tstatistik lebih besar dari nilai t-tabel $(2.135>1,96)$. Untuk hubungan PDO dalam variabel KKP sebesar 0,514 dan signifikan dengan t-statistik lebih besar dari nilai t-tabel $(3.046>1,96)$. Untuk hubungan KO dalam variabel KKP sebesar 0,794 dan signifikan dengan t-statistik lebih besar dari nilai t-tabel $(14.492>1,96)$. Dalam menilai model dengan PLS dimulai dengan melihat $R$-Square untuk setiap variabel laten dependen yang ditujukkan pada Tabel $R$-Square 
Tabel 4.6 R-Square

\begin{tabular}{|ll|}
\hline & R-square \\
\hline ISI & 0.000 \\
KK & 0.793 \\
KB & 0.839 \\
PP & 0.859 \\
UP & \\
\hline
\end{tabular}

Sumber: Output SmartPLS, 2019

Tabel tersebut menunjukkan nilai R-square konstruk komitment organisasi sebesar 0.899, dan kontribusi karyawan pensiun sebesar 0,982. Semakin tinggi $R$ square maka semakin besar variabel independen tersebut dapat menjelaskan variabel dependen, sehingga semakin baik persamaan struktural. Variabel komitment organisasi memiliki nilai $R$-square sebesar 0.899 yang berarti $89,9 \%$ komitment organisasi dipengaruhi oleh variabel keadilan organisasi dan persepsi dukungan organisasi, sedangkan sisanya $10.10 \%$ dipengaruhi oleh variabel yang lain. Untuk variabel kontribusi karyawan pensiun memiliki nilai $R$-square sebesar 0.982 yang berarti $98,2 \%$. kontribusi karyawan pensiun dipengaruhi oleh variabel keadilan organisasi, persepsi dukungan organisasi dan komitment organisasi sedangkan sisanya $13.20 \%$ dipengaruhi oleh variabel yang lain yang diteliti dalam penelitian ini (Ghozali, 2008).

\section{Pengujian dan Pembahasan Hipotesis \\ Keadilan Organisasi Berpengaruh Positif dengan Komitment Organisasi}

Berdasarkan hasil pengolahan data yang ditampilkan pada Tabel Result For Inner Weight, dapat diketahui bahwa nilai original sample estimate sebesar 0.218 dan nilai T-stasitik sebesar 4.380 adalah lebih besar dari T-tabel (1.96). Hasil data yang telah diolah tersebut dapat disimpulkan bahwa keadilan organisasi Berpengaruh positif dan signifikan dengan kontribusi karyawan pensiun. Dengan demikian $\mathrm{H} 1$ diterima. Hasil penelitian ini sesuai dengan penelitian Herda dan Lavelle (2011) yang menyatakan bahwa keadilan organisasi Berpengaruh positif dengan Kontribusi karyawan pensiun.

Hal ini sesuai dengan kenyataan di lapangan yang dapat dilihat dari jawaban responden pada kuesioner variabel keadilan organisasi, yaitu responden banyak yang menjawab dengan skala likert 4 dan 5 di mana responden merasakan adanya kesimbangan atas hasil kerja (gaji, bonus, perlakuan, persebaran informasi atau adanya promosi jabatan) dengan yang karyawan berikan kepada perusahaan, dan tentunya demi kepentingan perusahaan. Hal tersebut menyatakan bahwa karyawan pensiun PT Krakatau Steel telah mendapat keadilan organisasi sehingga memberikan efek positif jangka panjang kepada perusahaan dan memanifestasikan dirinya dalam bentuk kontribusi karyawan pensiun. Penelitian sebelumnya menunjukkan bahwa perlakuan yang adil oleh perusahaan sangat penting untuk mengembangkan hubungan pertukaran sosial (Lavelle et al., 2007.) 


\section{Keadilan Organisasi Berpengaruh Positif dengan Komitment Organisasi}

Berdasarkan hasil pengolahan data yang ditunjukan pada Tabel Result For Inner Weight, dapat diketahui bahwa nilai original sample estimate sebesar 0.218 dan nilai T-statistik sebesar 4.380 adalah lebih besar dari T-tabel (1.96). Hasil pengolahan data tersebut dapat disimpulkan bahwa keadilan organisasi Berpengaruh positif signifikan terhadap komitment organisasi.

Hasil penelitian ini mendukung hipotesis kedua sehingga $\mathrm{H} 2$ diterima. Hasil penelitian ini sesuai dengan penelitian Herda dan Lavelle (2011) yang menyatakan bahwa keadilan organisasi Berpengaruh positif dengan komitment organisasi.

Beberapa penelitian dan meta-analisis telah menunjukkan keadilan organisasi terhadap komitment organisasi yang akan langsung Berpengaruh dengan perilaku kontribusi pada organisasi (Burney, Henle, \& Widener, 2009; Cohen-Charash \& Spector, 2001; Colquitt, Conlon, Wesson, Porter, \& Ng , 2001; Lepine, Erez, \& Johnson, 2002; Moorman, 2001; Viswesvaran \& Ones, 2002). Model relasional keadilan organisasi (misalnya,Tyler \& Lind, 2002) menunjukkan bahwa perlakuan yang adil sangat penting untuk karyawan sebagian karena menyampaikan rasa memiliki dan melambangkan bahwa karyawan adalah anggota dihargai dan dihormati organisasi serta konsisten dengan perspektif ini.

Pada penelitian ini dikembangkan model yang menghubungkan pengaruh tidak langsung konstruk keadilan organisasi melalui komitment organisasi terhadap kontribusi karyawan pensiun. Untuk mengetahui pengaruh tidak langsung keadilan organisasi (KEO) terhadap kontribusi karyawan pensiun (KKP), dapat ditentukan dari penjumlahan pengaruh tidak langsung melalui variabel perantara komitment organisasi (KO).

\section{Komitment Organisasi Berpengaruh Positif dengan Kontribusi Karyawan Pensiun}

Berdasarkan hasil pengolahan data yang ditunjukan pada Tabel $R$-Square, dapat diketahui bahwa nilai original sample estimate sebesar 0.794 dan nilai Tstatistik sebesar 14.492 adalah lebih besar dari T-tabel (1.96). Hasil pengolahan data tersebut dapat disimpulkan bahwa komitment organisasi Berpengaruh positif signifikan terhadap kontribusi karyawan pensiun.

Hasil penelitian ini mendukung hipotesis ketiga sehingga $\mathrm{H} 3$ diterima. Hasil penelitian ini sesuai dengan penelitian Herda dan Lavelle (2011) yang menyatakan bahwa komitment organisasi Berpengaruh positif dengan kontribusi karyawan pensiun. Steers (1988) mengatakan komitmen organisasi menjelaskan kekuatan relatif dari sebuah identifikasi individu dengan keterlibatan dalam sebuah organisasi.

Komitmen menghadirkan sesuatu diluar loyalitas belaka terhadap suatu organisasi. disamping itu, hal ini meliputi suatu hubungan yang aktif dengan organisasi di mana individu bersedia untuk memberikan sesuatu dari diri mereka untuk membantu keberhasilan dan kemakmuran organisasi. 
Hasil penelitian ini didukung oleh Cropanzano \& Mitchell, 2005 yang menunjukkan bahwa komitmen organisasi dapat dilihat sebagai indikator sikap dari sejauh mana seorang karyawan memandang dirinya sendiri untuk berada dalam hubungan pertukaran sosial berkualitas tinggi dengan organisasi . Konsisten dengan penalaran ini, penelitian empiris baru-baru ini menunjukkan hubungan positif antara komitmen organisasi dan perilaku warga organisasi (Becker \& Kernan, 2003;. Lavelle et al, 2009).

Hal ini sesuai dengan kenyataan di lapangan yang dapat dilihat dari jawaban responden pada kuesioner variabel komitment organisasi, yaitu responden banyak yang menjawab dengan skala likert 4 dan 5 di mana komitment organisasi merupakan suatu sikap yang ditunjukkan oleh individu dengan adanya identifikasi, keterlibatan serta loyalitas terhadap organisasi. Serta, adanya keinginan untuk tetap berada dalam organisasi dan tidak bersedia untuk meninggalkan organisasinya dengan alasan apapun

\section{Persepsi Dukungan Organisasi Berpengaruh Positif dengan Komitment Organisasi.}

Berdasarkan hasil pengolahan data pada Tabel Result For Inner Weight menunjukkan bahwa persepsi dukungan organisasi Berpengaruh positif dan signifikan terhadap komitment organisasi yang ditampilkan dengan nilai original sample estimate sebesar 0.778 dan nilai T-statistik 16.944 adalah lebih besar dari T-tabel yaitu (1.96). Dengan demikian Hipotesis 4 diterima. Hasil penelitian ini mendukung penelitian sebelumnya Herda dan Lavelle (2011) memberikan bukti empiris bahwa persepsi dukungan organisasi secara positif Berpengaruh dengan komitment organisasi.

Dukungan organisasi dan komitmen organisasi adalah dua variabel yang telah digunakan sebagai indikator hubungan pertukaran sosial karyawan dengan organisasi. Para peneliti menunjukkan bahwa ketika karyawan merasa dukungan dari organisasi, karyawan akan merasakan suatu kewajiban untuk membalas dukungan yang dalam bentuk sikap yang menguntungkan terhadap organisasi, seperti komitmen (Lavelle et al., 2007).

\section{Persepsi Dukungan Organisasi Berpengaruh Positif dengan Kontribusi Karyawan Pensiun}

Berdasarkan hasil pengolahan data pada Tabel Result For Inner Weight menunjukkan bahwa komitment organisasi Berpengaruh positif dan signifikan terhadap kinerja organisasi yang ditampilkan dengan nilai original sample estimate sebesar 0.514 dan nilai T-statistik 3.046 adalah lebih besar dari T-tabel yaitu (1.96). Dengan demikian Hipotesis 5 diterima. Hasil penelitian ini mendukung penelitian sebelumnya Herda dan Lavelle (2011) memberikan bukti empiris bahwa persepsi dukungan organisasi secara positif Berpengaruh dengan kontribusi karyawan pensiun.

Persepsi terhadap dukungan organisasi mengacu pada persepsi karyawan mengenai sejauh mana organisasi menilai mereka dan peduli pada kesejahteraan mereka. Jika karyawan menganggap bahwa dukungan organisasi yang di terimanya tinggi, maka karyawan tersebut akan menyatukan keanggotaan sebagai 
anggota organisasi ke dalam identitas diri mereka dan kemudian mengembangkan hubungan dan persepsi yang lebih positif terhadap organisasi tersebut. Dengan menyatunya keanggotaan dalam organisasi dengan identitas karyawan, maka karyawan tersebut merasa bagian dari organisasi dan merasa bertanggung jawab untuk ber dan memberikan kinerja terbaiknya pada organisasinya. Penelitian yang dilakukan yang menggunakan sampel karyawan dari berbagai organisasi, (Rhoades, 2002: 705)

Hal ini sesuai dengan kenyataan di lapangan yang dapat dilihat dari jawaban responden pada kuesioner variabel persepsi dukungan organisasi, yaitu responden banyak yang menjawab dengan skala likert 4 dan 5 di mana menunjukkan bahwa ketika karyawan merasa mendapat dukungan dari organisasi, karyawan akan merasakan suatu kewajiban untuk membalas dukungan yang dalam bentuk sikap yang menguntungkan terhadap organisasi (Lavelle et al., 2007).

\section{KESIMPULAN}

Peneliti menggunakan pengujian SEM (Structural Equation Modelling) dengan menggunakan alat uji Smart PLS, dengan kesimpulan bahwa:

1. Keadilan organisasi berpengaruh positif dan signifikan dengan kontribusi karyawan pensiun, yang artinya hipotesis diterima. Hasil penelitian ini sesuai dengan penelitian Herda dan lavelle (2011) yang menyatakan bahwa keadilan organisasi berpengaruh positif dengan kontribusi karyawan pensiun. Artinya bahwa responden pada penelitian ini yakin bahwa peran keadilan organisasi membuat alumni pekerja masih berkontribusi terhadap perusahan

2. Keadilan organisasi berpengaruh positif dan signifikan terhadap komitment organisasi, yang artinya hipotesis diterima. Hasil penelitian ini sesuai dengan penelitian Herda dan Lavelle (2011) yang menyatakan bahwa keadilan organisasi berpengaruh positif dengan komitment organisasi. Artinya bahwa responden pada penelitian ini yakin bahwa peran keadilan organisasi membuat alumni pekerja merasa memiliki komitmen sehingga berkontribusi terhadap perusahan.

3. Persepsi dukungan organisasi berpengaruh positif dengan komitmen organisasi, yang artinya hipotesis diterima. Hasil penelitian ini sesuai dengan penelitian. Herda dan Lavelle (2011) yang menyatakan bahwa persepsi dukungan organisasi berpengaruh positif dengan komitment organisasi. Artinya bahwa responden pada penelitian ini yakin bahwa dukungan saat bekerja membuat alumni pekerja merasa memiliki komitmen sehingga berkontribusi terhadap perusahan.

4. Persepsi dukungan organisasi berpengaruh positif terhadap kontribusi karyawan pensiun. Hasil penelitian ini mendukung penelitian sebelumnya Herda dan Lavelle (2011) memberikan bukti empiris bahwa persepsi dukungan organisasi secara positif berpengaruh dengan kontribusi karyawan pensiun, artinya responden pada penelitian ini yakin bahwa memperlakukan 
karyawan dengan martabat, perhatian dan mendukung karyawan saat bekerja membuat alumni pekerja masih berkontribusi terhadap perusahan.

5. Komitment organisasi berpengaruh positif dan signifikan terhadap perubahan kontribusi karyawan pensiun. Hasil penelitian ini mendukung penelitian sebelumnya David dan Lavelle (2011) memberikan bukti empiris bahwa komitment organisasi secara positif berpengaruh terhadap kontribusi karyawan pensiun. Secara umum komitment organisasi diartikan sebagai kekuatan yang bersifat relatif dari individu dalam mengidentifikasikan keterlibatan dirinya kedalam bagian organisasi. Porter, Mowday dan Steers (1982). Artinya, komitment merupakan suatu sikap yang ditunjukkan oleh individu dengan adanya identifikasi, keterlibatan serta loyalitas terhadap organisasi. Serta, adanya keinginan untuk tetap berada dalam organisasi dan tidak bersedia untuk meninggalkan organnisasinya dengan alasan apapun.

\section{DAFTAR PUSTAKA}

Becker, J.U., Greve, G., Albers., S. (2009). The impact of technological and organizational implementation of CRM on customer acquisition, maintenance, and retention. Int. J. Res. Mark. 26 (3), 207-215.

Cohen - Carash, Y. \& Spector, P.E. (2001). The Role of Justice in Organizations :A Meta Analysis. Journal Of Organizational Behavior and Human Decision Processes, Vol. 86 No. 2, pp. 278 - 321.

Colquitt, J.A. (2001). On The Dimensionality Of Organizational Justice : A Construct Validation Of Measure. Journal Of Applied Psychology, Vol. 86, No. 3, pp. $\quad 386-400$.

Cropanzano, R., Bowen, D. E., \& Gilliland, S. W. (2007). The management of organizational justice. Academy of management perspectives, 21(4), 34-48

Cropanzano, R., \& Mitchell, M. (2005). Social exchange theory: An interdisciplinary review. Journal of Management, 31, 874-900.

Folger, R., \& Cropanzano, R. (1998). Organizational justice and human resource management. Beverly Hills, CA: Sage Publications.

Ghozali, Imam. (2006) . "Structural Equation Modeling Metode Alternatif Dengan Partial Least Square (PLS)”. Undip: Semarang.

Hasibuan, M. R. (2001). Pengaruh Karakteristik Perusahaan Terhadap Pengungkapan Sosial (Social Disclosures) Dalam Laporan Tahunan Emitmen Di Bursa Efek Jakarta Dan Bursa Efek Surabaya (Doctoral dissertation, program Pascasarjana Universitas Diponegoro).

Hasibuan, Malayu. (2001). Manajemen Sumber Daya Manusia:Pengertian Dasar, Pengertian, dan Masalah. Jakarta: PT. Toko Gunung Agung. 
Hasibuan, S.P. Malayu, (2004). Manajemen Sumber Daya Manusia, Dasar dan Kunci Keberhasilan. Jakarta: CV. Haji Masagung.

Kasemsap, K. (2012). Factor Affecting Organizational Citizenship Behavior of Passanger Car Plant Employees in Thailand. Journal of Social, Humanities, and Arts Silpakorn University Vol. 12(2). Suan Sunandha Rajabhat University: Bangkok.

Kreitner, Robert dan Angele Kinicki. (2003). Pengantar Organisasi Buku 1. Edisi Bahasa Indonesia. Jakarta: Salemba Empat.

Kuntjoro, H. Zainuddin Sri Drs, MPsi. (2002). Komitmen Organisasi. Jakarta.

Lavelle, J. J., Brockner, J., Konovsky, M. A., Price, K. H., Henley, A. B., Taneja, A., et al. (2009). Commitment, procedural fairness, and organizational citizenship behavior: A multifoci analysis. Journal of Organizational Behavior, 30, 337-357.

Luthans, Fred. (1995). Organizational Behavior, McGraw Hill International, New York.

Mardiana, Tri. (2004). Pengaruh Karakteristik individu Karakteristik Pekerjaan Dan Pengalaman Kerja Terhadap Komitmen Organisasi (Studi Empiris Pada Rumah Sakit Panti Rapih Yogyakarta., Telaah Bisnis, Nomor 2, 2004.

Marxen, DE (1996). The Big Six pengalaman. Sebuah account retrospektif oleh alumni. Akuntansi Horizons, 10 (2), 73-87.

Mathis, dan Jackson, 2002, Manajemen Sumber Daya Manusia, Edisi pertama, Cetakan Pertama, Yogyakarta : Salemba Empat.

Moorman, R. H. (1991). Relationship between organizational justice and organizational citizenship behaviors: Do fairness perceptions influence employee citizenship? Journal of Applied Psychology, 76, 845-855.

Moorman, R. H., Blakely, G. L., \& Niehoff, B. P. (1998). Does perceived organizational support mediate the relationship between procedural justice and organizational citizenship behavior? Academy of Management Journal, 41, 351-357.

Mowday, R. T., Steers, R. M., \& Porter, L. W. (1979). The measurement of organizational commitment. Journal of Vocational Behavior, 14, 224-247

Nawawi, Hadari. 1998.Metode Penelitian Bidang Sosial,Yogyakarta : Gadjah MadaUniversity Press.

Organ, D. W. (1988a). Organizational citizenship behavior: The good soldier syndrome. Lexington, MA: Lexington Books.

Organ, DW (1988a). Organisasi perilaku kewargaan: Sindrom prajurit yang baik. Lexington, MA: Lexington Books.

Organ, DW (1988b). Sebuah pernyataan kembali hipotesis kepuasankinerja. Jurnal Manajemen, 14, 547-557. 
Organ, DW (1990). Dasar motivasi perilaku kewargaan organisasional. Di BM Staw \& LL Cummings (Eds.). Penelitian dalam perilaku organisasi (Vol. 12, hlm 43-72). Greenwich, CT: JAI.

Parker, R. J., \& Kohlmeyer, J. M. III, (2005). Organizational justice and turnover in public accounting firms: A research note. Accounting, Organizations and Society, 30, 357-369.

Podsakoff, P. M., MacKenzie, S. B., Moorman, R. H., \& Fetter, R. (1990). Transformational leader behaviors and their effects on followers' trust in leader, satisfaction, and organizational citizenship behaviors. Leadership Quarterly, 1, 107-142.

Podsakoff, P., MacKenzie, S., Paine, J., \& Bachrach, D. (2000). Organizational citizenship behaviors: A critical review of the theoretical and empirical literature and suggestions for future research. Journal of Management, 26(3), 513-563.

Porter, M.E. (1980). Competitive strategy: techniques for analyzing industries and competitors. Free Press, New York, NY.

Porter, M.E. (1985). Competitive advantage: creating and sustaining superior performance. Free Press, New York, NY.

Rhoades, Linda. \& Eisenberger, Robert. (2002). Perceived organizational support: A review of the literature. Journal of applied psychology. 87(4): 698-714.

Robbins, S. \& Judge, T. (2008). Perilaku organisasi. (Terj. D. Angelica, R. Cahyani, dan A. Rosyid) Edisi 12. Jakarta: Salemba Empat. (Buku asli tahun 2007)

Setiadi, 2004. Manajemen Kinerja. Semarang: Graha Ilmu.

Thibaut, J. W. and Kelley, H. H. (1959) The social Psychology of Groups, New York: Wiley.

Triyanto, A. \& Santosa, TEC. (2009). Organizational Citizenship Behavior (OCB) dan Pengaruhnya Terhadap Keinginan Keluar dan Kepuasan Kerja Karyawan. Jurnal Manajemen Vol. 7 No. 4. Universitas Kristen Maranatha. 